\title{
TCEANA
}

\section{Illegal Fishing and Human Rights Abuses at Sea: Using Technology to Highlight Suspicious Behaviors}

\author{
June 2019 \\ DOI: 10.31230/osf.io/juh98

\section{Executive Summary}

Illegal, unregulated and unreported (IUU) fishing ${ }^{a}$ undermines the responsible management of commercial fishing and ocean conservation. It exploits the natural resources of coastal nations, reduces economic opportunity and threatens food security. IUU fishing is a low-risk, high-reward activity, especially on the high seas where a fragmented legal framework and lack of effective enforcement allows it to thrive. With global fish populations declining, vessels must travel farther and fish longer to remain profitable. Some unscrupulous vessels are involved in other illegal activities to further cut costs and drive up profits, including the use of forced labor and other human rights abuses. By detecting patterns in fishing vessel behaviors that are associated with IUU fishing, forced labor and human trafficking, emerging technologies and vessel tracking can help identify suspicious activity and potentially disrupt the environments in which these crimes thrive.

Oceana analyzed the activity of two currently active fishing vessels and one refrigerated cargo vessel; two of the vessels were previously involved in confirmed cases of forced labor and IUU fishing, and one vessel was suspected of IUU fishing and involvement in human trafficking. Oceana used the Global Fishing Watch ${ }^{\mathrm{b}}$ (GFW) mapping platform (www.globalfishingwatch.org) to detect

\footnotetext{
a Illegal fishing is any violation of fishing laws within a State's jurisdiction or internationally agreed upon fishing laws and regulations, including those of a Regional Fisheries Management Organization (RFMO). Unreported fishing is any fishing activity that is unreported or deliberately misreported to the national authority or relevant RFMO. Unregulated fishing includes fishing conducted by a vessel without nationality, fishing in an RFMO-managed area by a vessel with a nationality not party to that RFMO, or fishing where there are no management measures in place.

${ }^{b}$ Any and all references to "fishing" should be understood in the context of Global Fishing Watch's fishing detection algorithm, which is a best effort to determine "apparent fishing effort" based on vessel speed and direction data from the Automatic Identification System (AIS) collected via satellites and terrestrial receivers. As AIS data varies in completeness, accuracy and quality, and the fishing detection algorithm is a statistical estimate of apparent fishing activity, it is possible that some fishing effort is not identified and conversely, that some fishing effort identified is not fishing. For these reasons, Global Fishing Watch qualifies all designations of vessel fishing effort, including synonyms of the term "fishing effort," such as "fishing" or "fishing activity," as "apparent," rather than certain. Any/all Global Fishing Watch information about "apparent fishing effort" should be considered an estimate and must be relied upon solely at your own risk. Global Fishing Watch is taking steps to make sure fishing effort designations are as accurate as possible.
} 


\section{OCEANA}

and analyze the activities of these vessels over time. Using GFW data, in combination with both publicly available information and data from a research nonprofit, Oceana found that:

- The South Korean-flagged fishing vessel Oyang 77 appeared to repeatedly stop transmitting its Automatic Identification System (AIS) and has a known history of noncompliance, including illegal fishing and involvement in human rights abuse cases. Over an almost five-year period, Oceana detected 73 apparent gaps in AIS transmissions immediately outside of Argentina's national waters. Four additional gaps in AIS appeared within Argentina's national waters, one of which lasted almost 12 days and ended when the Argentine Coast Guard captured the vessel for fishing illegally.

- The Taiwanese-flagged fishing vessel Hung Yu 212 - on which a victim of alleged human trafficking perished during a 2011 voyage - remained at sea for an extended period of up to 20 months from 2015 through 2017 while fishing in the South Atlantic Ocean.

- The refrigerated cargo vessel Renown Reefer conducted an illegal transshipment off the coast of Somalia in 2017. Subsequently, the vessel moved from port-to-port in an apparent effort to unload its catch and avoid sanctions. Because the port States in the region shared communications that this vessel was trying to enter port after engaging in IUU fishing, the Renown Reefer was prevented from landing its catch. This vessel was previously identified by the Indonesian government for its association with human trafficking.

These case studies reveal that vessels with a history of non-compliance can exhibit potentially suspicious patterns of behavior like remaining at sea for extended periods of time, evading public tracking systems and avoiding ports known to enforce regulations. These activities are generally regarded as suspicious by intergovernmental organizations, international organizations, other non-governmental organizations and researchers. Poor oversight, weak international legal frameworks, and lack of transparency in ownership and supply chains make commercial fishing a vulnerable sector for illicit activity, including IUU fishing, human trafficking and forced labor.

To stop illegal fishing and other criminal activities at sea, we need to see beyond our shores and expand transparency of commercial fishing. Oceana is working with governments to expand AIS use at sea; provide public access to Vessel Monitoring Systems (VMS) data; and release key information about fishing authorizations. With increased transparency, we can see what is happening beyond the horizon and tackle the threats facing our oceans.

\section{IUU Fishing Intertwined with Criminal Activity on the High Seas}

Healthy and abundant oceans are essential because seafood provides a critical source of protein for millions of people around the world. The global demand for seafood has more than doubled since the 1960s and is estimated to continue to rise. Unfortunately, overfishing is reducing seafood landings globally, in some places dramatically. One-third of global fish populations are overexploited, and more than half are fully exploited with no room for growth. ${ }^{1}$ Overfishing is not only detrimental to food security, but also threatens the livelihoods of fishers and the health of our oceans. 


\section{OCEANA}

Overfishing is exacerbated by IUU fishing. Exceeding catch limits, falsifying catch documents and fishing in protected areas are all examples of IUU fishing. These actions not only contribute to overfishing, but also give illegal fishermen an unfair advantage over those that play by the rules. A decade ago, illegal and unreported fishing was estimated to result in $\$ 23.5$ billion in global economic losses - equivalent to approximately 26 million metric tons of seafood stolen from the oceans every year ${ }^{2}$ - and these estimates are likely even higher today. Honest fishermen and seafood businesses are forced to compete with illegally caught fish that enters the market. In the United States alone, 20 to 32 percent of wild-caught seafood imports are estimated to be from illegal and unreported catch. ${ }^{3}$ Not only does IUU fishing exploit the natural resources of coastal nations, reduce economic opportunity and threaten food security, it is also intertwined with other criminal activities on the high seas.

When fishing companies engage in IUU fishing on a large, systemic scale, it can be considered transnational organized crime. ${ }^{4,5} \mathrm{IUU}$ fishing is estimated to be the sixth largest transnational criminal enterprise by revenue, ${ }^{5}$ offering high rewards while posing little risk. The potential for IUU fishing is especially great on the high seas where fisheries management and enforcement are often insufficient and sometimes inconsistent. ${ }^{6,7}$

The amount of commercial fishing on the high seas has increased as coastal fish stocks decline. Subsequently, operating costs have also increased as vessels move farther from shore to fish. ${ }^{8,9}$ Efforts to reduce the costs of fishing operations, like certain government subsidies, can result in the overcapacity of fishing fleets and may lead to an increase in the amount of IUU fishing. ${ }^{10,11}$ IUU fishing vessels are already evading laws, regulations and oversight to gain higher profits, and in some cases, are more willing to drive down costs by exploiting workers through forced labor and human trafficking. ${ }^{5,12}$

The same conditions that make the high seas vulnerable to IUU fishing also make it susceptible to other forms of transnational organized crime. IUU fishing has been linked to a range of illicit activities, including document forgery, money laundering, forced labor, and human, drug and wildlife trafficking. ${ }^{4,7}$ Evading monitoring, enforcement and regulation allows IUU fishing and other illegal activities to continue. 


\section{OCEANA}

\section{Fisheries Management on the High Seas ${ }^{13}$}

An Exclusive Economic Zone (EEZ) is an area of ocean that is governed by the adjacent nation. It typically extends 200 nautical miles from the coast and is where the country has sole jurisdiction over fisheries resources. The area outside an EEZ is considered international waters or the 'high seas.'

\section{Flag State:}

Country where the vessel is registered. Responsible for regulating vessel activity on the high seas, as well as in coastal or port States, including authorized fishing inside an EEZ.

Regulatory Weakness:

- Flag State may be a Flag of Non-Compliance (FoNC), which is a vessel registered to a country that is unwilling or ineffective at monitoring and controlling vessel activity

\section{Coastal State:}

Responsible for regulating vessel activity within waters under the country's jurisdiction.

Regulatory Weakness:

- May be limited by resources to enforce laws and regulations

- No authority to regulate vessels on the high seas

\section{Port State:}

Responsible for ports in its territory (conducts port inspections, can deny port entry, determines the requirements for vessel identity and activities for port entry).

\section{Regulatory Weakness:}

- Port State may be a Port of Convenience (PoC), which is a port States that is unable or unwilling to inspect vessels and enforce fisheries laws

\section{Regional Fisheries Management Organizations (RFMOs):}

Composed of countries with fishing interests in the region, RFMOs are charged with managing internationally shared fisheries resources (sometimes only specific fisheries) and fishing areas, most of which are found on the high seas.

Responsibilities include:

- Authorization of fishing and transshipment vessels in the RFMO

- Management of allowable catch from fisheries in the RFMO

- Identification and listing of IUU fishing vessels

\section{Regulatory Weakness:}

- Inconsistent regulatory powers and measures across RFMOs

- RFMO decisions are generally made by representatives from all members, noncontracting parties and observers, making consensus difficult 


\section{OCEANA}

\section{Certain Vessel Patterns Signal a Potential Increased Risk of Illegal Activity at Sea}

By identifying patterns of vessel activity that indicate a potential higher risk of IUU fishing, human rights abuses and other transnational organized criminal activity, governments can target enforcement and inspections of suspicious vessels. When cross-checked with a historic record of non-compliance with fisheries or labor laws (e.g. Regional Fisheries Management Organization listing of IUU vessels or government prosecution for illegal activities), certain vessel activity patterns can serve as warning signs to identify vessels that may warrant further investigation or inspection. Some of the suspicious vessel patterns that can be observed through examining vessel movements include transshipping, port avoidance and apparent gaps in public vessel tracking data, such as AIS. These activities are generally regarded as suspicious by intergovernmental organizations, international organizations, other non-governmental organizations and researchers. ${ }^{9,15-21}$ Oceana used Global Fishing Watch data to generate maps that exemplify certain vessel activities, which may signal an increased risk of illegal fishing.

\section{History of Vessel Noncompliance}

The lack of transparency in the fishing industry complicates efforts to identify current ownership of fishing vessels or the vessel's history..$^{15,16}$ Without knowledge of vessel ownership or history, it is difficult to enforce fisheries regulations and laws and prosecute criminal activity at sea. ${ }^{15}$ The transparency of vessel ownership and the ability to enforce fisheries regulations are greatly affected by the owner's choice of flag State (the country where a vessel is registered). Under international law, a flag State is required to monitor and control the activities of all vessels registered to fly its flag. ${ }^{22}$ A "flag of convenience" is when a nation operates an open registry and sells its flag to a foreign vessel. This can permit vessel owners to register their ships at low costs with little or no oversight ${ }^{23}$ and can allow fishers to evade the conservation and management regulations of their own country. When a vessel is registered to a country that is unwilling or ineffective at monitoring and controlling vessel activity, it is considered to be operating under a Flag of Non-Compliance (FoNC). FoNCs enable vessels to avoid scrutiny for IUU fishing. ${ }^{16,20} \mathrm{~A}$ vessel may frequently change its name and flag State to hide its history, and in some cases, the government responsible for controlling its activities. ${ }^{15,16}$ By avoiding transparency about ownership, flag State and history, a vessel can more easily evade enforcement and engage in IUU fishing as well as other forms of criminal activity such as fraud, forced labor and smuggling. $7,15,24$

\section{Gaps in AIS Tracking Data}

A vessel with AIS automatically broadcasts a signal with vessel identity, location, speed and direction as frequently as once every few seconds. ${ }^{25}$ Large vessels, such as cargo vessels and all cruise ships, are required by the International Maritime Organization (IMO) to carry AIS, ${ }^{\mathrm{c}}$ but individual countries can decide how these requirements apply to fishing vessels flying their flag or fishing in their waters. Thus, not all fishing vessels are required to be equipped with AIS or to

\footnotetext{
c The International Maritime Organization (IMO) International Convention for the Safety of Life at Sea (SOLAS) requires AIS to be fitted aboard all international voyaging ships of 300 gross tonnage and upwards, cargo ships of 500 gross tonnage and upwards not engaged on international voyages and all passenger ships regardless of size. (Chapter V, Regulation 19 of the 1974 SOLAS Convention).
} 


\section{OCEANA}

continually transmit AIS tracking data. There are legitimate causes for loss of AIS signals such as poor satellite coverage and certain regions where the density of vessels transmitting AIS signals is so high that the ability for the receiver to collect all the signals is compromised. However, vessel operators can also deliberately "go dark" by turning off their AIS devices to appear invisible to public maritime tracking systems. For example, Figure 1 displays the track of a fishing vessel that appeared to turn off its AIS for 15 days as it moved towards the Galapagos Islands Marine Protected Area where industrial fishing is prohibited, ${ }^{26}$ protecting one of the most biologically diverse regions in the world. ${ }^{27}$

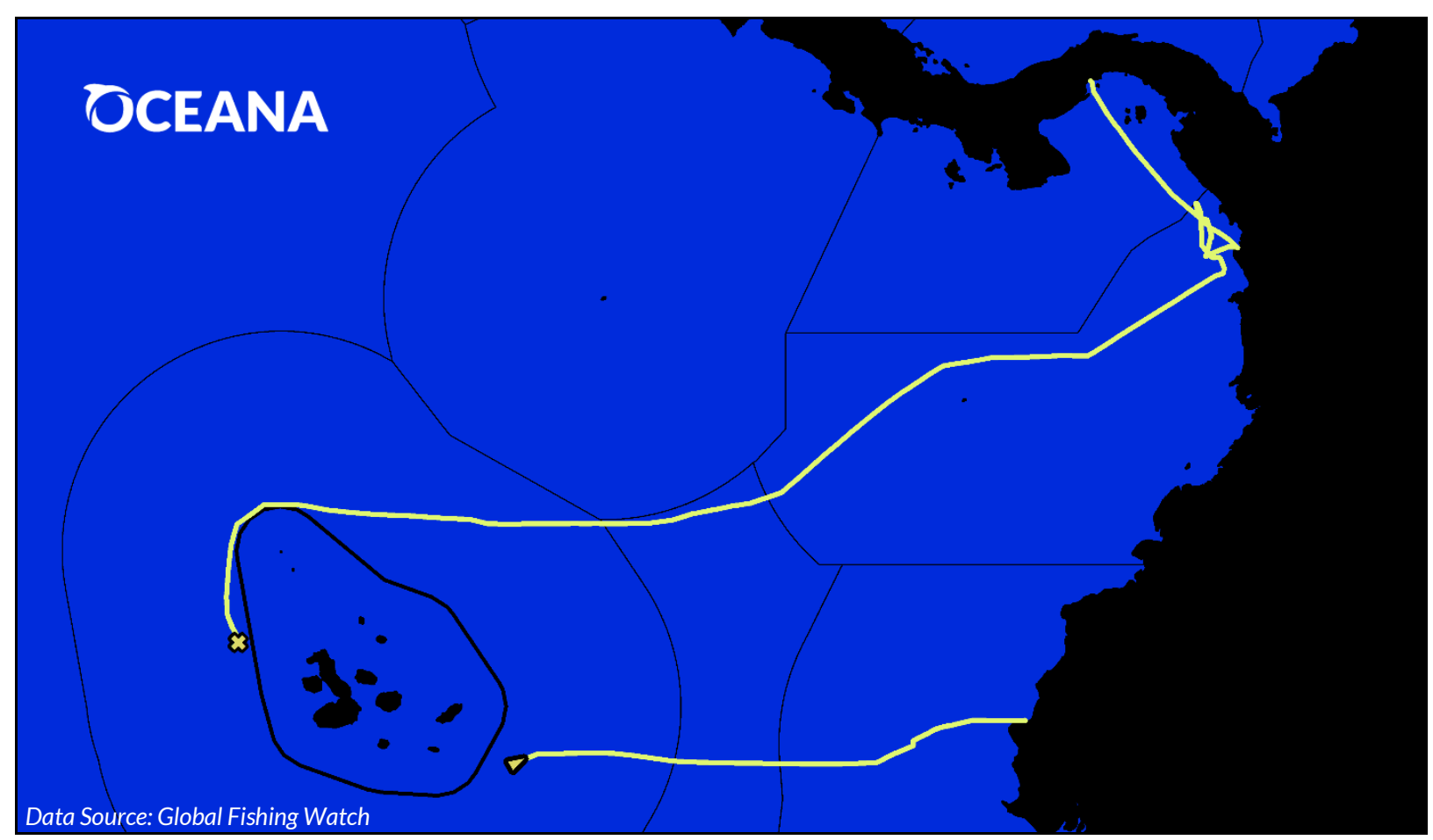

Figure 1. A vessel (track shown in yellow) can be seen leaving Panama and eventually moving towards the coast of Ecuador. The vessel disappears from AIS public tracking (yellow $\mathrm{x}$ ) and reappears (yellow triangle) 15 days later near the other side of the Galápagos Marine Reserve border.

There are legitimate reasons for a vessel to turn off its AIS, such as concerns for the safety and security of the ship and crew in areas prone to piracy. ${ }^{28}$ However, it raises suspicion when AIS is off for an extended period near a protected area or a coastal nation's Exclusive Economic Zone (EEZ) that does not permit fishing by foreign-flagged vessels. AIS avoidance can be used to hide IUU fishing or other criminal activities, such as transshipment of illegally caught fish or other illicit cargo, and fishing in unauthorized locations. ${ }^{9,15,17}$

\section{Transshipping and Time at Sea}

Transshipping, or the transfer of fish or other supplies from a fishing vessel to a refrigerated cargo vessel (or "reefer"), is often legal but can facilitate illegal fish laundering. For example, IUU-caught fish can be mixed with legally caught fish on the reefer; ${ }^{8}$ transferring fish to another vessel to aid 


\section{OCEANA}

in the misreporting of catch can exacerbate the problem of overfishing. People, drugs and other items can also be moved during transshipments. ${ }^{15,18}$

While transshipping is a common global practice, it enables vessels to stay out at sea for extended periods of time. For example, the fishing vessel shown in Figure 2 was at sea for a total of 525 days, during which it transshipped with at least one reefer. ${ }^{29}$ Transshipping can help lead to overcapacity in the fishing industry by decreasing travel costs and increasing time spent at sea, ${ }^{8}$ which in turn can instigate overfishing, IUU fishing and other illicit activities. Not all flag or coastal States have the capacity or political will to monitor fishing activity in their waters or on vessels flagged to their countries.

Additionally, crew members that are victims of forced labor or human trafficking may be stranded on fishing vessels for years without returning to land.$^{15}$ If workers are being forced to work aboard a vessel, the crew may not be allowed to leave the fishing vessel, and when they return to land, their travel may be restricted because their passports and documentation can be withheld., ${ }^{9,21}$ While at sea, abuses and poor working conditions are difficult to monitor and identify because of the isolated nature of distant water fishing, potentially long periods at sea, and weak regulatory enforcement on the high seas. ${ }^{9,21}$ Attempting to address this and deter forced labor, Thailand implemented a 30-day maximum time at sea for commercial fishing vessels. ${ }^{30}$

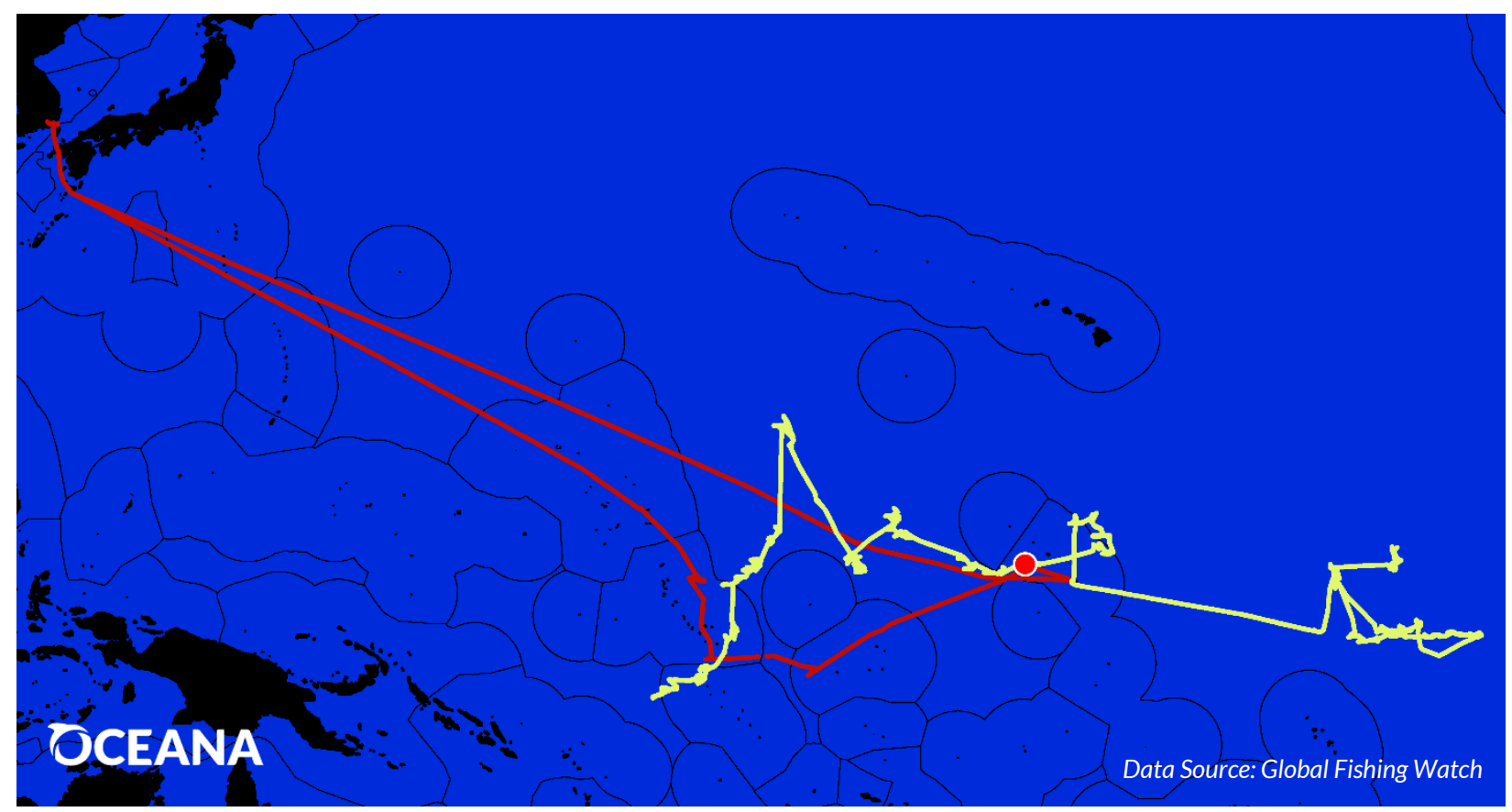

Figure 2. Fishing vessel (yellow track) likely transshipped (red circle) with a cargo vessel (red track) in the Pacific Ocean 10 months after leaving port.

\section{Port Avoidance}

The Port State Measures Agreement (PSMA) was entered into force in June $2016 .{ }^{31}$ This international treaty prevents, deters and eliminates IUU fishing by requiring that foreign fishing 


\section{OCEANA}

vessels meet certain conditions prior to gaining access to a country's port. As of March 2019, 59 countries and the European Union were party to the PSMA. ${ }^{32}$ If a vessel seeking port access is suspected of IUU fishing, a vessel's history may be reviewed, an inspection can be conducted, and port entry can be denied. The results of the inspection are then transmitted not only to the flag State, but also to relevant parties such as the country in which IUU fishing occurred and any associated Regional Fishery Management Organization (RFMO). ${ }^{31}$ Flag States that are parties to the PSMA are required to respond to action requested by the port State if the vessel is suspected of IUU fishing. ${ }^{31}$ Eventually, reefers and fishing vessels must enter port to unload catch, conduct ship maintenance and repairs, or resupply. Vessels involved in criminal activity may avoid entering ports of countries that are party to the PSMA (Figure 3), and instead choose to enter ports of convenience $(\mathrm{PoC})$, which are port States that are unable or unwilling to inspect vessels and enforce fisheries laws. ${ }^{15,19}$

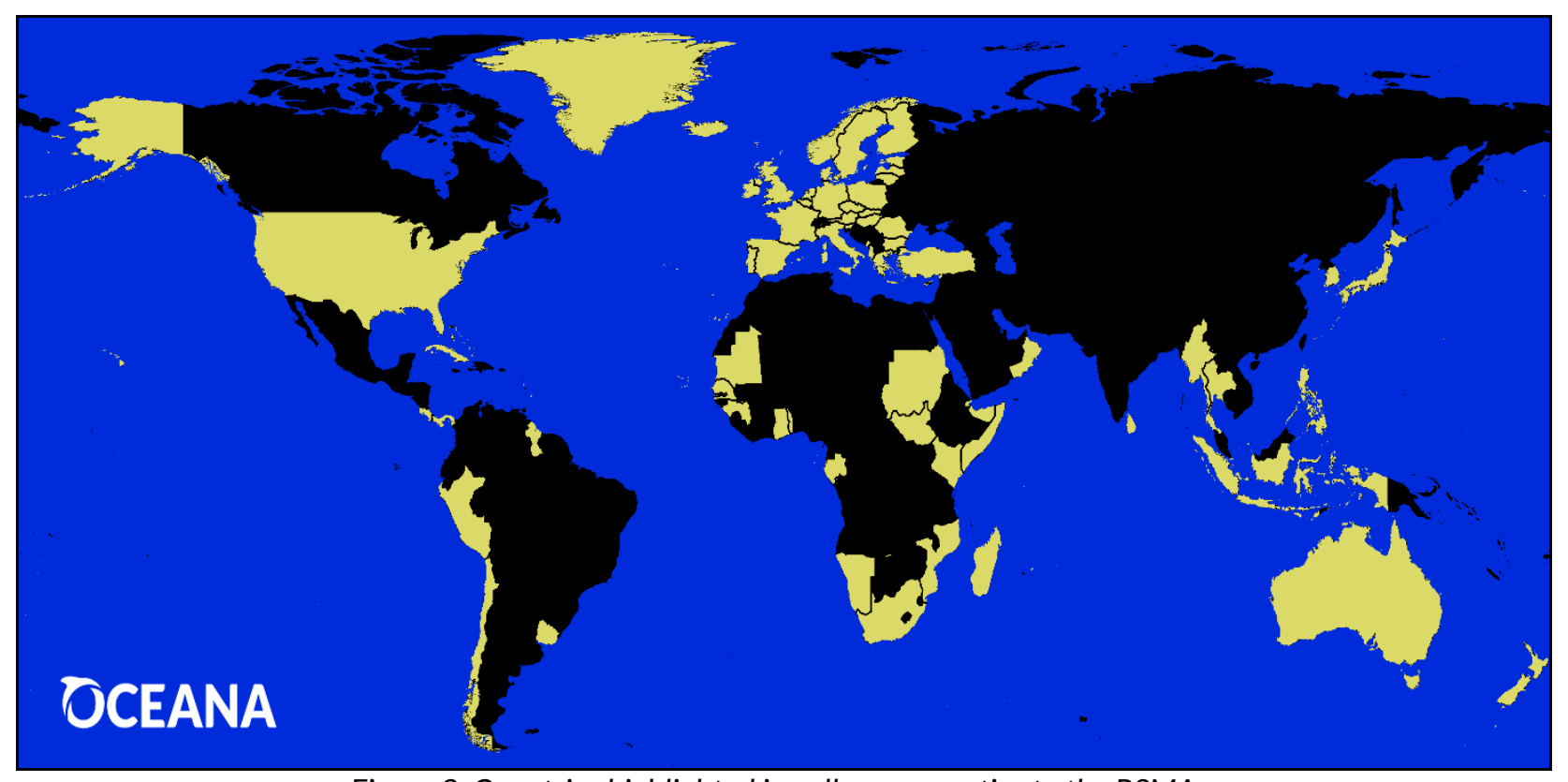

Figure 3. Countries highlighted in yellow are parties to the PSMA.

\section{Visualizing Suspicious Vessel Activity}

Oceana worked with a non-governmental research organization to investigate three case studies of vessels with a known history of involvement in IUU fishing and forced labor or human trafficking. The three case studies highlighted in this report were selected after investigating and identifying records of non-compliance by the vessel, as well as available vessel track data through February 2019, which appears to show patterns of activity that can indicate a higher risk of illicit activities, such as apparent AIS avoidance, transshipment, extended periods at sea and PSMA port avoidance. These case studies demonstrate how vessels with a history of non-compliance can engage in suspicious activities and exploit weak regulatory frameworks to potentially fish illegally or facilitate other criminal activities on the high seas like forced labor and human trafficking. 


\section{OCEANA}

Human Trafficking and Forced Labor

\section{What is Human Trafficking and Forced Labor?}

Human trafficking is the fastest growing transnational criminal enterprise in the world, generating $\$ 150$ billion dollars annually and enslaving an estimated 21.9 million people. ${ }^{33}$ Human trafficking is defined by the United Nations' Protocol to Prevent, Suppress and Punish Trafficking in Persons as: "The recruitment, transportation, transfer, harboring or receipt of persons, by means of the threat or use of force or other forms of coercion, of abduction, of fraud, of deception, of the abuse of power or of a position of vulnerability or of the giving or receiving of payments or benefits to achieve the consent of a person having control over another person, for the purpose of exploitation."

Forced labor, as defined by the International Labor Organization (ILO) - a United Nations agency that sets labor standards and develops programs to ensure proper working conditions - is "work that is performed involuntarily and under the menace of any penalty. It refers to situations in which persons are coerced to work through the use of violence or intimidation, or by more subtle means such as manipulated debt, retention of identity papers or threats of denunciation to immigration authorities." ${ }^{34}$

\section{What is Human Trafficking and Forced Labor in the Seafood Industry?}

The seafood supply chain is complex, opaque and difficult to trace. It starts at sea and follows a winding path from fishing vessel to reefer, from reefer to reefer, from vessel to factories, from factories to processing, out to market, and then onward for global distribution. Human trafficking and forced labor can occur at every step in the supply chain. Human trafficking in fisheries entails the transfer and containment of persons onboard vessels, where they are forced to work as crew by means of violence, threat or debt. Victims of forced labor in fisheries are often migrant workers without a support network. Victims of forced labor are often isolated in inhumane conditions onboard fishing vessels, trapped at sea for extended periods of time. Crew members can be subjected to a range of forced labor abuses including physical, psychological and sexual abuse; unsanitary and unsafe working conditions; 20-hour workdays; lack of pay; and even murder. ${ }^{24,35}$ IUU fishing vessels have been known to subsidize costs using forced labor exploitation, as they are already evading laws, regulations and oversight to drive profits and may be more willing to exploit workers. ${ }^{12,24}$ 


\section{OCEANA}

Oceana used data from the GFW mapping platform to detect and visualize vessel activity patterns. GFW empowers anyone, including governments, journalists, researchers and the public, to view or download data and investigate global fishing activity in near real-time, for free. GFW uses machine learning to detect the fishing activity and gear type used by more than 70,000 fishing vessels. The fishing detection algorithm classifies fishing or non-fishing (i.e. transiting) activity based on information collected in the global feed of AIS data, such as speed, direction and rate of turn. In addition, GFW developed methods to detect certain voyage events, such as possible port visits, possible transshipment between vessels and apparent gaps in AIS transmission. See the Appendix for detailed methods of event detection.

\section{Vessel Case Studies}

Oceana used the GFW database to investigate patterns in the movements of commercial fishing and refrigerated cargo vessels previously involved in documented cases of forced labor abuses and IUU fishing. For each case study, Oceana matched a unique vessel identifier - the IMO ship identification number - to the vessel database provided by GFW and then collected all available GFW data. For each case study vessel, Oceana examined GFW data from January 2012 (when the GFW dataset starts - any documented IUU fishing or forced labor cases that occurred prior to when GFW data was available were not analyzed) through February 2019, including all transit activity, possible fishing activity, possible port visits, possible transshipment activity and apparent gaps in AIS transmission. Each of the case studies illustrated in this report highlights a different pattern of vessel activity associated with possible IUU fishing and possible forced labor abuses; each raises questions that call for further investigation.

\section{Case Study 1: A History of Illegal Fishing and Labor Abuses with a Pattern of AIS Avoidance}

\section{History of Non-Compliance}

In 2011, the New Zealand government recorded complaints about vessel safety, living and working conditions, physical and sexual abuse by officers, underpayment and manipulation of time sheets, most which appeared to occur on Korean-flagged vessels. ${ }^{36}$ During that same time, the U.S. Department of State documented allegations of forced labor as well as withholding or underpaying wages on South Korean-flagged vessels in New Zealand waters. ${ }^{37}$

From 2010 through 2012, three South Korean-flagged vessels, owned and operated by the same South Korean company, fished in New Zealand waters under a chartering agreement with a New Zealand company. One of these vessels, the Oyang 70, sank in August 2010, killing six people. ${ }^{38}$ In December 2011, New Zealand's Ministry of Fisheries charged the captain of a second vessel, the Oyang 77, with various fisheries-related offenses, including the illegal dumping of fish and the underreporting of catch. ${ }^{39,40}$ In September 2014, fines totaling 120,500 New Zealand dollars (approximately $\$ 80,000$ USD) were imposed on the captain. ${ }^{40}$ Subsequently, the New Zealand Crown seized the Oyang 77 and its sister ship, the Oyang $75 .^{38}$

In March 2018, the New Zealand Supreme Court ruled that crew members from the Oyang 77 and the Oyang 70 were owed unpaid wages and entitled to a claim for relief against the forfeited 


\section{OCEANA}

Oyang 77 and Oyang 75 vessels. ${ }^{41}$ The Supreme Court noted, however, that the Oyang 77 and Oyang 75 were both previously released under bond and were no longer in New Zealand waters. ${ }^{42}$

Almost one year later, in February 2019, Argentina's Coast Guard captured the Oyang 77 for fishing illegally within its EEZ, ${ }^{43}$ finding more than 142,000 kilograms of hake, haddock, rays and squid onboard. ${ }^{44}$ The vessel owner paid 25 million Argentine pesos (approximately $\$ 550,000$ USD) to Argentina's government, and the Oyang 77's fishing equipment was confiscated before the vessel was later released in March 2019.44

\section{Suspicious Vessel Patterns}

The southwest Atlantic Ocean has rich fishing grounds, attracting long distance foreign fishing fleets in search of squid and other species. Argentina, which borders a high seas fishing area, has a history of battling IUU fishing inside its EEZ. ${ }^{45}$ For example, Argentine authorities have previously shot and sunk Chinese fishing vessels and captured a Spanish vessel under suspicion of fishing illegally within its EEZ. ${ }^{46-48}$ Foreign-flagged vessels are not permitted to fish inside its EEZ unless they comply with the strict regulations outlined in Argentina's Fisheries Law. ${ }^{49}$

Many of the foreign-flagged fishing vessels that are active in the southwest Atlantic Ocean including Chinese, Spanish, South Korean and Taiwanese fishing vessels - have apparent gaps in their AIS transmissions in areas along Argentina's EEZ. ${ }^{50}$ These gaps raise questions, because disabling AIS hides the vessel from public monitoring. The fishing hot spot directly outside of the Argentine EEZ is only managed for tuna and remains unregulated for other fisheries. This lack of regulation can embolden vessels to illegally fish or engage in other illicit activities, including forced labor. ${ }^{15,51,52}$

From April 2014 through February 2019, the Oyang 77 fished off the coast of South America, just outside Argentina's EEZ. Using GFW data, Oceana tracked a consistent pattern of apparent gaps in AIS transmission by the Oyang 77, which has a known history of non-compliance, including illegal fishing and human rights abuses..$^{53}$ This vessel appeared to have 77 gaps in its AIS transmission with each occurrence lasting at least 48 hours (Figure 4).

Seventy-three of these apparent gaps occurred within 60 kilometers of the Argentine EEZ (Figure 4). On four occasions, the AIS transponder appeared to stop transmitting while within Argentina's EEZ: January 23, 2017 for nearly 18 days (422 hours), January 19, 2019 for more than two days (53 hours), January 23, 2019 for more than two days (57 hours) and January 27, 2019 for nearly 12 days (283 hours). On the last occasion, the AIS signal for the Oyang 77 started transmitting again on February 7, 2019 - the same day that the Argentine Coast Guard captured the vessel for fishing illegally within its EEZ, with more than 142,000 kilograms of fish onboard (Figure 5).

Oceana reached out to the owner of the Oyang 77 for comment but did not receive a response. ${ }^{54}$ To help end IUU fishing and other crimes at sea, it is critical to increase transparency on the high seas through mandatory, publicly accessible and tamper-resistant AIS paired with VMS monitoring systems. Vessels with a history of non-compliance, including IUU fishing, forced labor, and repeated AIS avoidance, warrant increased oversight and further investigation by associated flag and coastal States. 


\section{OCEANA}

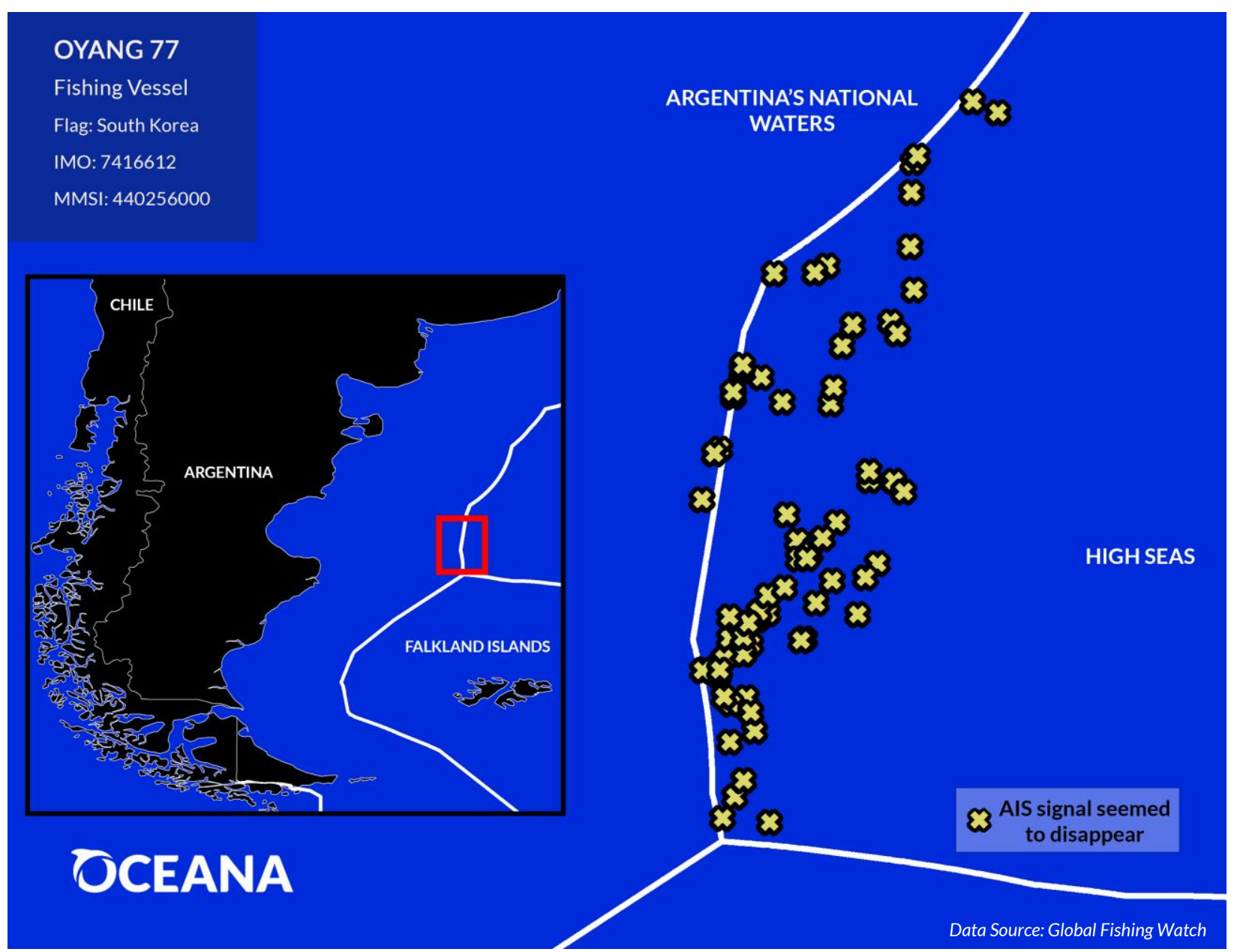

Figure 4. From April 2014 through February 2019, the Oyang 77 exhibited 77 apparent gaps in AIS transmission, four of which occurred in Argentina's national waters and 73 of which occurred on the high seas, within 60 kilometers of the Argentine EEZ. 


\section{OCEANA}

\section{OCEANA}

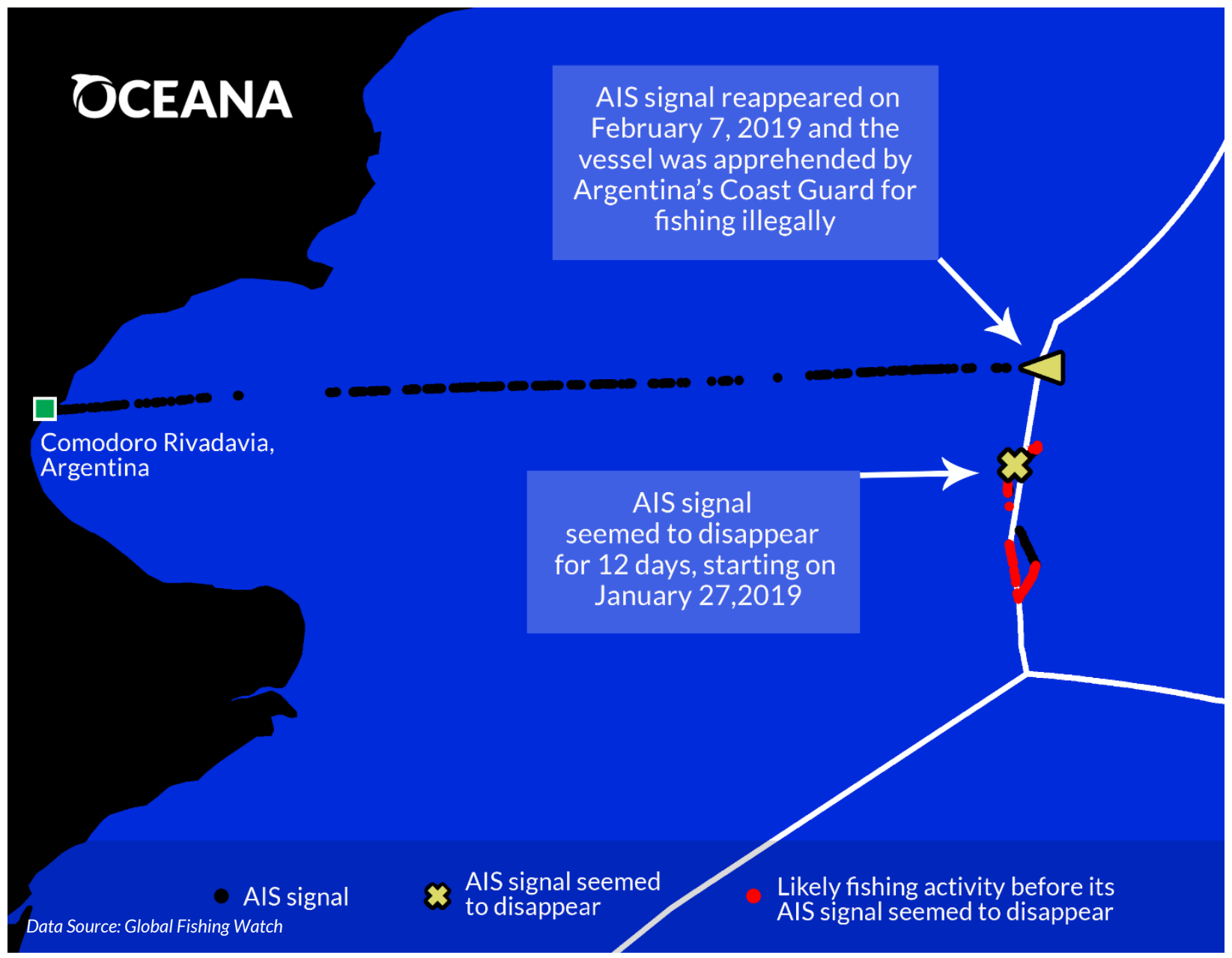

Figure 5. The Oyang 77 appeared to fish on the high seas and inside Argentina's EEZ before its AIS signal seemed to disappear for nearly 12 days, starting on January 27, 2019. The vessel's AIS signal reappeared on February 7, 2019 on the day it was caught by Argentina's Coast Guard for fishing illegally and was brought to port in Comodoro

Rivadavia, Argentina. 


\section{OCEANA}

Case Study 2: Previous Human Trafficking and Current Long-Term Duration at Sea

\section{History of Non-Compliance}

The Hung Yu 212 is a Taiwanese-flagged fishing vessel with a history of suspected IUU fishing and involvement in human trafficking. In 2011, this fishing vessel was cited by the Indian Ocean Tuna Commission (IOTC) for inadequately recording its fishing activity. ${ }^{55}$ During the same year, a Filipino victim of alleged human trafficking died while working as a crew member onboard this vessel in the Indian Ocean. ${ }^{56}$ This story was detailed in The New York Times article "Tricked and Indebted on Land, Abused or Abandoned at Sea." ${ }^{77, d}$ In response to a request for comment, The Fisheries Agency of Taiwan stated: "We found that the body of [the person] was shipped to Singapore, and the autopsy report made by Singapore Health Sciences Authority indicated that the cause of death is acute myocarditis." ${ }^{58}$ However, a second autopsy reported by the Philippine National Police described contradictory results, concluding the cause of death was a heart attack and noting bruises on the face and chest inflicted prior to death. ${ }^{59,60}$ The Philippine National Police charged individuals involved with recruiting the victim with human trafficking crimes. ${ }^{61}$ The vessel ownership has not changed from the time of the fisherman's death, and in 2018, the International Commission for the Conservation of Atlantic Tuna (ICCAT) authorized the vessel to fish and transship with reefers in the Atlantic Ocean. ${ }^{62-64}$

\section{Suspicious Vessel Patterns}

Between May 2015 and 2017, the Hung Yu 212 demonstrated a consistent pattern of fishing in the southern Atlantic Ocean and anchoring in Cape Town, South Africa (Figure 6). This vessel appeared to have only entered port in Cape Town twice since 2015, which raises questions as to whether it had potentially been out at sea without entering port for nearly 20 months. GFW data indicated, and the Fisheries Agency of Taiwan confirmed, that the vessel entered port in Cape Town, South Africa on July 20, 2015 and stayed through October 8, 2015. ${ }^{65}$ In addition, GFW data indicated, and the Fisheries Agency of Taiwan confirmed, that the vessel docked at the same port from May 26, 2017 to July 19, 2017. ${ }^{65}$ Although unlikely, it is possible that some port entries were not identified through AIS transmissions, as this vessel does have apparent gaps in its AIS transmissions throughout its time at sea. The gaps in AIS transmission cannot be assumed to be suspicious since the Hung Yu 212 has a type of AIS device that reports less often and at a lower power than AIS transponders that emit a higher-priority signal more frequently, which may result in certain AIS transmissions being missed. Gaps in AIS transmissions could also be due to low and inconsistent satellite coverage in the area. ${ }^{66}$ Based on maximum vessel speed, distance and timing of apparent gaps in AIS transmissions, Oceana concluded that this vessel was out at sea for at least one period of a minimum of five months. Although this vessel is not required to return to port after

\footnotetext{
d The 2015 New York Times report "Tricked and Indebted on Land, Abused or Abandoned at Sea" by lan Urbina has a secondary set of complied documents, entitled "A Suspicious Death," (https://www.nytimes.com/interactive/2015/11/06/world/asia/document-first-draft-documentreader.html) which include several supporting documents for the report, specifically: the first and second autopsy report of the victim and the investigation report by the Philippine national police. These supporting documents are cited in the case study.
} 


\section{OCEANA}

a certain period of time, the longer a vessel is out at sea, the longer crew members are isolated aboard the vessel.

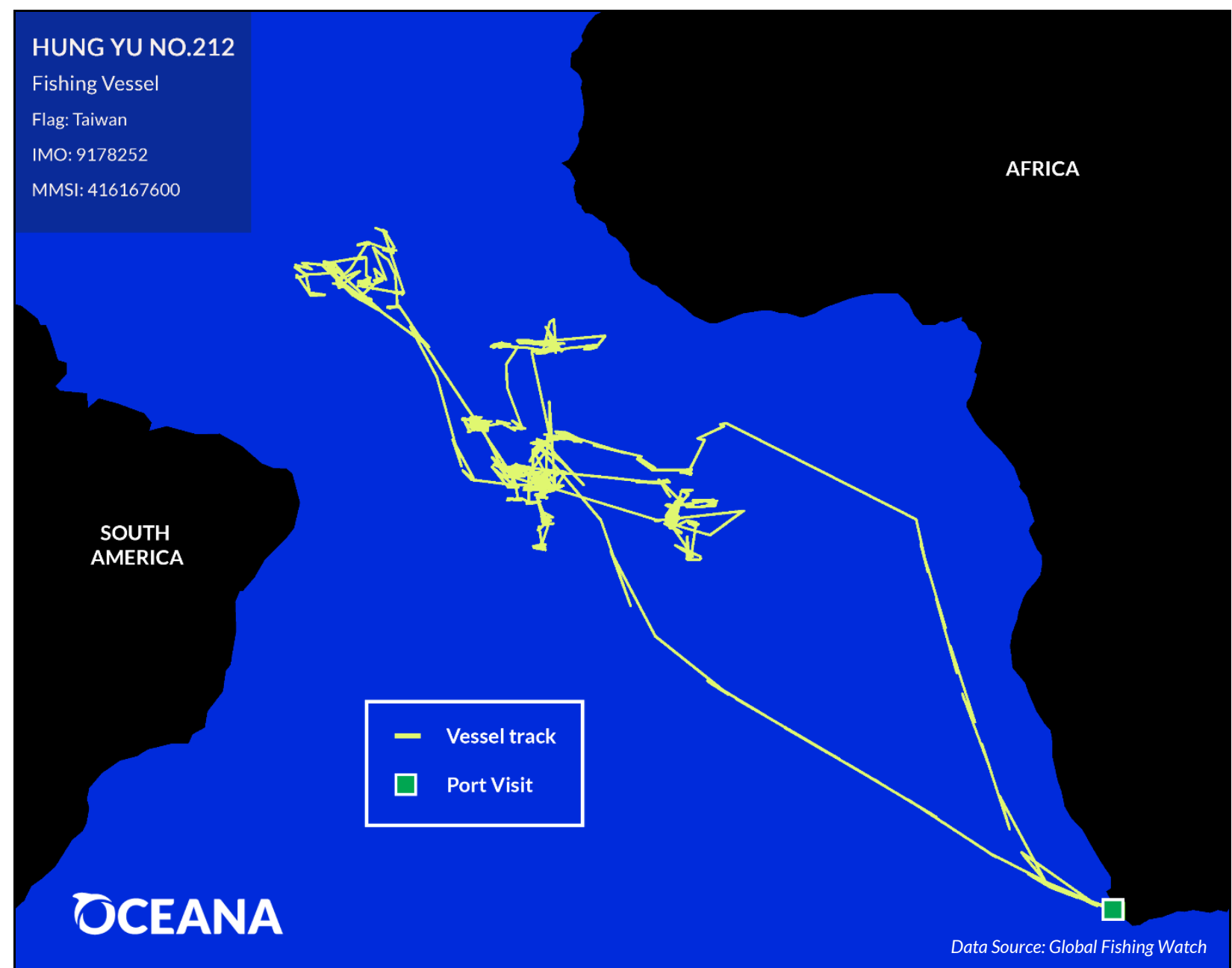

Figure 6. Hung Yu 212 fished in the southern Atlantic Ocean for two years and appeared to only enter port twice between 2015 and 2017.

Oceana reached out to the flag State of Taiwan for comment regarding the activity of the Hung Yu 212. The Fisheries Agency of Taiwan stated that "the reception of the said vessel's VMS transmission was totally normal and consistent with our requirement" throughout the period of identified gaps in AIS transmission. ${ }^{58}$ In addition, the Fisheries Agency of Taiwan stated that "staying out at sea is by no means relevant to the conditions and rights of workers on board," because "fishing workers usually leave fishing vessels and go onshore (or vice versa) with supply vessels, just like the deployment of our domestic observers." ${ }^{\text {" } 5}$ The Fisheries Agency also noted that "no [sic] any report regarding your concern has been provided by the crew or observers on board." ${ }^{\prime \prime}$ In addition to the government of Taiwan, Oceana reached out to the owners of the Hung Yu 212 for comment but did not receive a response. ${ }^{67}$ 


\section{OCEANA}

The vessel's history of involvement in human trafficking, combined with the possibility that this vessel was out at sea for at least five months and up to 20 months, suggest that further inspection of the vessel and crew is advisable to determine the treatment of crew and the conditions onboard the vessel.

Case Study 3: Association with Notorious Fishing Company and Recent IUU Listing for Illegal Transshipment

\section{History of Non-Compliance}

Since 2015, the waters surrounding Indonesia, including the Banda and Arafura seas, have been publicly highlighted as hotspots for IUU fishing and human trafficking. ${ }^{68}$ The 2015 Associated Press investigation "Slaves may have caught the fish you bought" ${ }^{69}$ aided the Indonesian government in investigating a fishing fleet of approximately 90 vessels involved in human trafficking and IUU fishing in Indonesian waters. ${ }^{68,70}$ The year-long investigation detailed human trafficking conducted across the fleet of vessels in the region. In 2015, the Indonesian government revoked the license of the fishing company registered as the operator of the inspected vessels after an investigation by the government confirmed forced labor and human trafficking. ${ }^{71}$ Eight people associated with the fishing fleet were arrested, charged and convicted of human trafficking crimes. $^{72-79}$ The Indonesian government continues to take steps to reduce criminal activity at sea, including establishing a human rights certification process for fishing vessels ${ }^{71}$ and publishing their VMS data on the GFW mapping platform to expand transparency of commercial fishing.

\section{Suspicious Vessel Patterns}

One reefer that had been licensed under and chartered by the company referenced above, continued to illustrate suspicious activity during 2017. In May 2018, the Wisdom Sea Reefer (now named Renown Reefer) was added to the list of IUU vessels by the IOTC for involvement in IUU fishing. ${ }^{80}$ Satellite imagery presented as evidence for the IOTC listing shows illegal transshipment conducted by the Honduras-flagged Wisdom Sea Reefer on April 27, 2017 off the coast of Somalia. ${ }^{81}$ This evidence is validated by Oceana's analysis using GFW data (Figure 7). After this event, GFW data show a series of port avoidance movements as a response to intergovernmental communication about the reefer's illegal activities. All port States of the IOTC are responsible for IUU information exchange and other measures as part of the IOTC Port State Measures Resolution, which was developed based on the PSMA. ${ }^{82}$ In July 2017, the reefer requested port entry in Taiwan. Citing the PSMA, Taiwan prepared to board and inspect the reefer after Thailand, party to the PSMA, warned them of the vessel's potential involvement in IUU fishing. The reefer decided to leave Taiwanese waters before entering port, but Taiwan still conducted an at-sea inspection before the vessel left. Taiwan communicated suspicious findings from the inspection to the surrounding countries, the flag State of Honduras and the flag State of Djibouti, which was the flag State of the other fishing vessels involved in the illegal activity. ${ }^{81,83}$ According to vessel documentation attached to a letter from the Director General of the Fisheries Administration of Cambodia to the IOTC Secretary, the reefer briefly ported in Vietnam and Malaysia before moving towards Cambodia by the end of $2017 .{ }^{81}$ The reefer entered Cambodia as the "Renown Reefer" and was flagged to Bolivia. ${ }^{81}$ Australia, a party to the PSMA, informed Cambodia of the reefer's 


\section{OCEANA}

IUU fishing activity and Cambodian authorities proceeded to inspect the vessel and relay their findings to the IOTC and The International Criminal Police Organization (INTERPOL). ${ }^{81}$

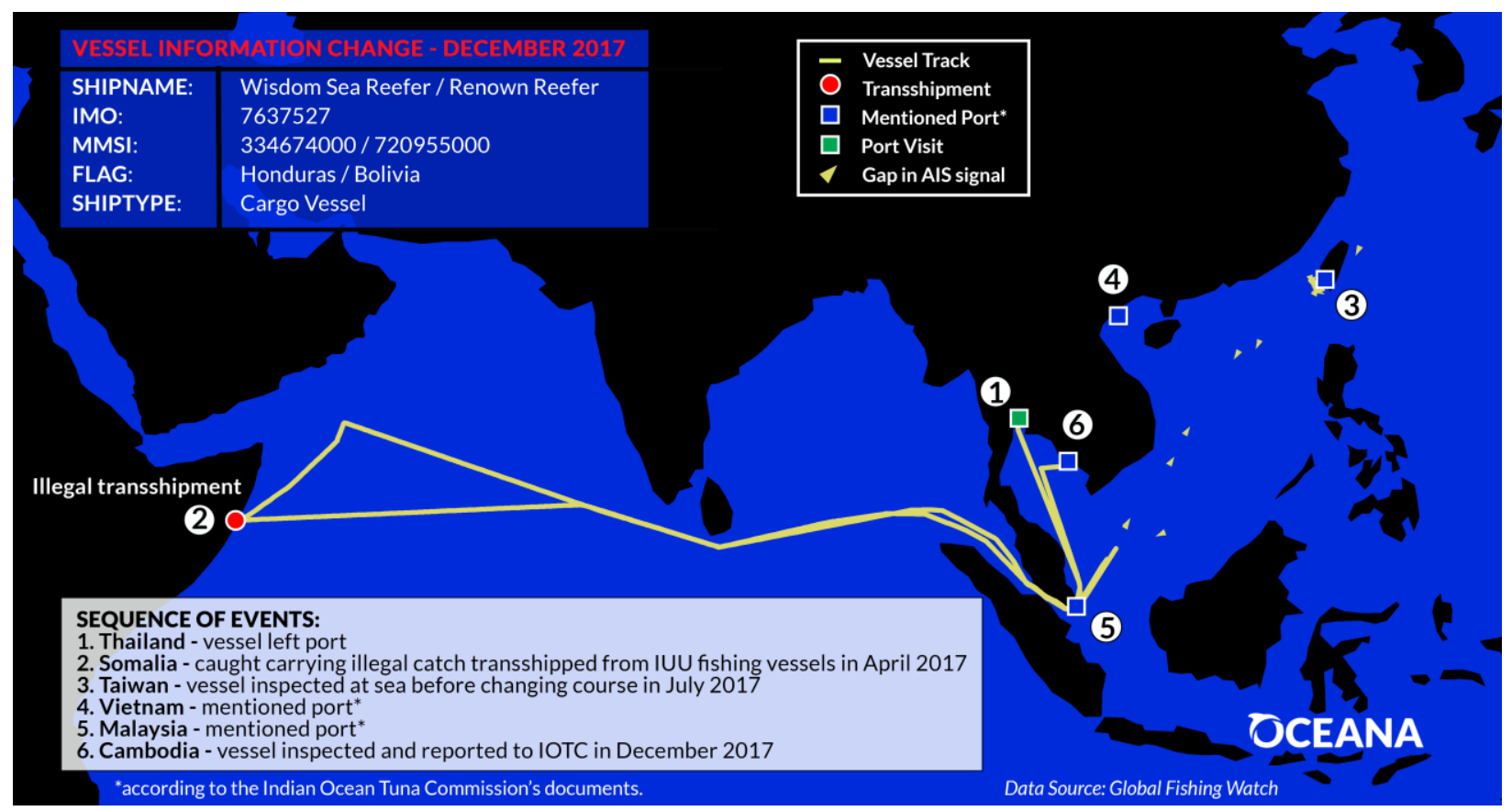

Figure 7. The Renown Reefer conducted an illegal transshipment off the coast of Somalia and soon after moved from port-to-port to land catch and apparently avoid sanctions.

This case study provides a clear example of the link between a vessel's history of non-compliance, suspicious vessel movements and illicit activity. The Renown Reefer was not only chartered by an infamous fishing fleet involved in human trafficking, but it also switched from one FoNC to another and moved from port-to-port to land catch and avoid sanctions after conducting an illegal transshipment. The exchange of information among the European Union, IOTC, flag States, port States and coastal States - in part enacted by measures required by the IOTC Port State Measures Resolution and PSMA - was critical for understanding and tracking this vessel's activity. The listing of the Renown Reefer as an IUU vessel by the IOTC is an example of how global communication and information exchange is critical to disrupt illegal activity.

\section{Recommendations}

The case studies presented in this report demonstrate how vessel tracking data can signal suspicious vessel activities that may warrant further investigation and help end IUU fishing and human rights abuses at sea. Each vessel highlighted had a documented or suspected history of involvement in forced labor or human trafficking and in some cases IUU fishing; yet each vessel continued to fish and exhibited patterns of activity that raise suspicion of continued illegal activity at sea. Some vessel activity patterns may more readily indicate IUU fishing than certain forced labor abuses that may not be as visible, such as poor working conditions on the vessel. However, transshipment, apparent gaps in public tracking systems and port avoidance can hide illegal 


\section{OCEANA}

activity at sea, enabling both human rights abuses and IUU fishing. Oceana, using GFW data, has shown that vessels with a history of non-compliance may warrant further investigation by the flag State and governing bodies where the vessels operate - including coastal States, port States and RFMOs - to ensure such vessels are no longer involved in any illegal activity. Vessels with a prior history of non-compliance are not the only suspected culprits, as each fishing vessel is often just one component of a larger chain of complex operations, management and ownership that, if investigated further, may reveal an even greater network of IUU fishing and forced labor practices around the world.

To help end illegal fishing and human rights abuses at sea, Oceana recommends the following:

Ban Transshipment at Sea: RFMOs should require that transshipping only occurs at ports where authorities can closely monitor the exchange. For example, the South East Atlantic Fisheries Organization has implemented a total ban on at-sea transshipment, ${ }^{84}$ and other RFMOs should follow suit.

Expand Vessel Transparency: All coastal and flag State governments and RFMOs should mandate constant use of tamper-resistant AIS and VMS devices by commercial fishing vessels that fish within their waters or carry their flag. For example, the European Union requires fishing vessels greater than 15 meters in length to be equipped with and continually transmit AIS. ${ }^{85}$

Increase Publicly Available Vessel Information: Before awarding a license or authorization, flag and coastal States should require information on the managers, operators and owners of the vessel. Flag and coastal States, as well as all RFMOs, should maintain publicly available, up-to-date vessel registries that include the unique vessel identifier numbers, licenses, permit payments and vessel ownership. Countries should implement the requirements of the Fisheries Transparency Initiative (FiTI) standard to help ensure fisheries transparency, including publishing information on foreign fishing access agreements, fisheries law and regulations, and labor standards in the fishing sector. ${ }^{86}$ Governments should work with groups like Oceana and Global Fishing Watch to utilize vessel tracking information to improve risk-based enforcement and identify vessels that may warrant additional scrutiny.

Develop Intergovernmental Lists of Vessels Engaged in Forced Labor: In cooperation with RFMOs, the International Labor Organization (ILO) and the IMO should work with their members to create a list of vessels with track records of human rights abuses, including forced labor practices and human trafficking, to facilitate knowledge-sharing and deter criminal activity.

Uphold Flag and Coastal State Responsibilities: Flag States must enforce relevant fishing regulations for their flagged fleet, no matter where it fishes - on the high seas, in waters managed by an RFMO or in the territorial waters of coastal States. Flag States should ensure effective monitoring and control, institute a strong legal framework to prosecute IUU fishing activity, and exchange information within the country and internationally. Vessels with a history of IUU fishing or labor violations should not be awarded fishing authorizations. Coastal States should allow access to foreign fleets only when proper monitoring and control can be executed and should become signatories to the PSMA. 


\section{OCEANA}

\section{Conclusion}

Some fishing vessels around the world continue to chase profits while ignoring fisheries and labor laws. Suspicious activities like transshipping, remaining at sea for extended periods of time, apparent gaps in vessel tracking and port avoidance can signal a higher risk of IUU fishing, forced labor and other human rights abuses. The owners of these vessels often face little-to-no repercussions for IUU fishing or other criminal activities because they are masking their history of non-compliance by changing flag States, and obscuring information about ownership, vessel authorization and registration. Governments should discourage these behaviors by enacting policies that increase transparency and deter illegal activity.

The lack of transparency in the fishing industry allows IUU fishing, forced labor, human trafficking and other criminal activities to continue in the dark. By requiring greater transparency of commercial fishing, we can help stop IUU fishing and forced labor abuses at sea, leading to more responsibly managed fisheries worldwide.

\section{Acknowledgements}

Oceana would like to thank Valerie Farabee of Liberty Shared for contributing to the research, writing and review of this report, including in-depth knowledge of transnational human trafficking arrangements and modi operandi. Oceana would also like to acknowledge the contributions of Oceana staff and an anonymous external reviewer to this report. 


\section{OCEANA}

\section{References}

1. -- (2018) The State of World Fisheries and Aquaculture 2018 - Meeting the sustainable development goals. Food and Agriculture Organization.

2. Agnew DJ, Pearce J, Pramod G, et al. (2009) Estimating the worldwide extent of illegal fishing. PLoS ONE 4 doi: 10.1371/journal.pone.0004570

3. Pramod G, Nakamura K, Pitcher TJ and Delagran L (2014) Estimates of illegal and unreported fish in seafood imports to the USA. Marine Policy Elsevier.48: 102-113. doi: 10.1016/j.marpol.2014.03.019

4. Haenlein C (2017) Below the Surface: How Illegal, Unreported and Unregulated Fishing Threatens our Security. Royal United Services Institue.

5. May C (2017) Transnational Crime and the Developing World. Global Financial Integrity.

6. -- (2016) Global Implications of Illegal, Unreported, and Unregulated (IUU) Fishing. National Intelligence Council.

7. Bondaroff TNP, Van Der Werf W and Reitano T (2015) The Illegal Fishing and Organized Crime Nexus: Illegal Fishing as Transnational Organized Crime. The Global Initiative : 84.

8. Ewell C, Cullis-Suzuki S, Ediger M, et al. (2017) Potential ecological and social benefits of a moratorium on transshipment on the high seas. Marine Policy Elsevier Ltd.81: 293-300. doi: 10.1016/j.marpol.2017.04.004

$9 . \quad--$ (2013) Caught at sea : forced labour and trafficking in fisheries. International Labour Office, Special Action Programme to Combat Forced Labour (DECLARATION/SAP-FL), Sectoral Activities Department (SECTOR).

10. Sumaila UR, Lam V, Le Manach F, Swartz W and Pauly D (2016) Global fisheries subsidies: An updated estimate. Marine Policy 69: 189-193. doi: 10.1016/j.marpol.2015.12.026

11. -- (2016) The State of World Fisheries and Aquaculture 2016. Contributing to food security and nutrition for all. Food and Agriculture Organization.

12. -- (2010) All at Sea - The Abuse of Human Rights aboard Illegal Fishing Vessels. Environmental Justice Foundation.

13. FAO (2002) Implementation of the International Plan of Action to Prevent, Deter and Eliminate Illegal, Unreported and Unregulated Fishing. In: FAO Technical Guidelines for Responsible Fisheries. No. 9. Rome.

14. -- (2012) FAQ: What is a Regional Fishery Management Organization? In: The Pew Charitable Trusts. Available: https://www.pewtrusts.org/en/research-and-analysis/factsheets/2012/02/23/faq-what-is-a-regional-fishery-management-organization. Accessed Feb 12, 2019.

15. -- (2011) Transnational organized crime in the fishing industry - Focus on: Trafficking in Persons Smuggling of Migrants Illicit Drugs Trafficking. United Nations Office on Drugs and Crime.

16. -- (2017) Chasing Red Herrings: Flags of Convenience, Secrecy and the Impact on Fisheries Crime Law Enforcement. North Atlantic Fisheries Intelligence Group.

17. -- (2018) The potential use of "automatic identification systems - AIS" as a fisheries monitoring tool. Stop Illegal Fishing.

18. -- (2015) Pirates and Slaves - How Overfishing in Thailand Fuels Human Trafficking and the Plundering of Our Oceans. Environmental Justice Foundation.

19. Telesetsky A (2015) Laundering Fish in the Global Undercurrents: Illegal, Unreported, and 


\section{OCEANA}

Unregulated Fishing and Transnational Organized Crime. Ecology Law Quarterly 41: 939997. doi: 10.15779/Z38656G

20. Miller DD and Sumaila UR (2014) Flag use behavior and IUU activity within the international fishing fleet: Refining definitions and identifying areas of concern. Marine Policy 44: 204-211. doi: http://dx.doi.org/10.1016/j.marpol.2013.08.027

21. Surtees R (2018) Trapped at Sea. Using the Legal and Regulatory Framework to Prevent and Combat the Trafficking of Seafarers and Fishers. Groningen Journal of International Law 1: 91. doi: 10.21827/5a86a7a0dd73c

22. -- (1982) United Nations Convention on the Law of the Sea of 10 December 1982. Articles 92 and 94.

23. Zwinge T (2011) Duties of Flag States to Implement and Enforce International Standards and Regulations - And Measures to Counter Their Failure to Do So. Journal of International Business and Law 10 doi: 10.2139/ssrn.1682193

24. -- (2017) Stretching the Fishnet: Identifying Opportunities to Address Fisheries Crime. United Nations Office on Drugs and Crime.

25. -- (2015) AIS Requirements. United Stated Coast Guard. Available: https://www.navcen.uscg.gov/?pageName=AISRequirementsRev. Accessed Dec 12, 2018.

26. -- (1998) Ley de Régimen Especial para la Conservación y Desarrollo Sustentable de la Provincia de Galápagos. Congreso Nacional del Ecuador.

27. -- Galápagos Island. UNESCO World Heritage Centre. Available: http://whc.unesco.org/en/list/1. Accessed Feb 1, 2019.

28. -- (2002) Resolution A.917(22) Guidelines for the onboard operational use of shipborne automatic identification systems (AIS). International Maritime Organization.

29. Malarky L and Lowell B (2017) No More Hiding at Sea: Transshipping Exposed. Oceana.

30. -- (2017) Press Release: At Seattle Seafood Summit, Thailand joins NGOs, corporate and partners to fight illegal fishing and labor abuses. Royal Thai Embassy.

31. -- (2016) Agreement on Port State Measures to Prevent, Deter and Eliminate Illegal, Unreported and Unregulated Fishing. Revised Edition. Food and Agriculture Organization.

32. -- Agreement on Port State Measures (PSMA) - Parties to the PSMA. Food and Agriculture Organization. Available: http://www.fao.org/port-state-measures/background/partiespsma/en/. Accessed May 10, 2019.

33. -- (2014) Profits and poverty: the economics of forced labour. International Labour Office.

34. -- (2018) What is forced labour, modern slavery and human trafficking. International Labour Organization. Available: https://www.ilo.org/global/topics/forcedlabour/definition/lang--en/index.htm. Accessed May 9, 2018.

35. -- (2015) GAPfish: Global Action Programme against forced labour and trafficking of fishers at sea. International Labour Organization. Available: https://www.ilo.org/wcmsp5/groups/public/---ed_norm/--declaration/documents/publication/wcms_429359.pdf. Accessed May 9, 2018.

36. -- (2012) Report of the Ministerial Inquiry into the use and operation of Foreign Charter Vessels at paras. [107], [110-114], [413]. New Zealand Ministry for Primary Industries.

37. -- (2012) Trafficking in Persons Report. US State Department.

38. -- HARTONO v THE MINISTRY FOR PRIMARY INDUSTRIES [2015] NZHC 3307 [18 December 2015 re- issued 22 February 2016] at para. [4].

39. -- SOUTHERN STORM FISHING (2007) LIMITED v THE DIRECTOR GENERAL OF THE 


\section{TCEANA}

MINISTRY FOR PRIMARY INDUSTRIES [2014] NZHC 3087 [28 November 2014] at paras. [4], [8].

40. -- (2014) Trawler forfeited, heavy fine for fish dumping. New Zealand Ministry for Primary Industries. Available: https://www.mpi.govt.nz/news-and-resources/mediareleases/trawler-forfeited-heavy-fine-for-fish-dumping/. Accessed Mar 20, 2019.

41. -- RUDI HARTONO AND OTHERS v MINISTRY FOR PRIMARY INDUSTRIES [2018] NZSC 17 [2 March 2018].

42. -- SAJO OYANG CORPORATION AND RUDI HARTONO AND 29 OTHERS $V$ THE MINISTRY FOR PRIMARY INDUSTRIES [2018] NZHC 3041 [22 November 2018].

43. -- (2019) Prefectura custodia al pesquero surcoreano capturado en el Mar Argentino. Prefectura Naval Argentina. Available:

https://www.prefecturanaval.gob.ar/cs/Satellite?d=\&c=Noticia_C\&pagename=Instituciona I_Publico\%2FNoticia_C\%2FNoticiaSinEncabezado\&cid=1436817987185? Id=6419. Accessed Mar 21, 2019.

44. -- (2019) El Estado Argentino recuperó casi 25.000.000 de pesos por la captura de un pesquero detectado por Prefectura dentro de la Zona Económica Exclusiva. Prefectura Naval Argentina. Available:

https://www.prefecturanaval.gob.ar/cs/Satellite?d=\&c=Noticia_C\&pagename=Instituciona I_Publico\%2FNoticia_C\%2FNoticiaSinEncabezado\&cid=1436817987185? Id=10819. Accessed Mar 21, 2019.

45. Sustainable Fisheries Partnership (2016) Argentine shortfin squid - SW Atlantic.

46. Profeta D (2018) The South Atlantic is a Scrum of the World's Illegal Fishing Vessels. The News Lens. Available: https://international.thenewslens.com/article/91191. Accessed May 9, 2018.

47. Schvartzman M (2016) Argentina's patience snaps on China's illegal fishing. China Dialogue. Available: https://www.chinadialogue.net/article/show/single/en/8934-Argentina-spatience-snaps-on-China-s-illegal-fishing. Accessed May 9, 2018.

48. -- (2016) Is Argentina on the verge of a new conflict with Uruguay? Fish Information and Services. Available: https://www.fis.com/fis/worldnews/worldnews.asp?monthyear=32016\&day=7\&id $=82827 \& l=e \&$ country $=\&$ special $=\& n d b=1 \& d f=1$. Accessed May 9, 2018.

49. Consejo Federal Pesquero (2009) Régimen Federal de Pesca. Ley 24.922.

50. Cutlip K (2017) What Can We See When AIS Signals Disappear? IUU Watch. Available: http://www.iuuwatch.eu/2017/08/can-see-ais-signals-disappear/. Accessed May 9, 2018.

51. Dunn DC, Jablonicky C, Crespo GO, et al. (2018) Empowering high seas governance with satellite vessel tracking data. Fish and Fisheries 19: 729-739. doi: 10.1111/faf.12285

52. Marschke $M$ and Vandergeest $P$ (2016) Slavery scandals: Unpacking labour challenges and policy responses within the off-shore fisheries sector. Marine Policy 68: 39-46. doi: 10.1016/j.marpol.2016.02.009

53. -- Sources on file with Oceana.

54. -- Letter from Oceana to vessel representative (May 3, 2019) (on file with Oceana).

55. Nugent P, Wissema J, Clark JM and Cariglia N (2012) A Summary of the IOTC Regional Observer Programme During 2011.

56. Yea S (2012) Troubled Waters: TraffickingTrafficking of Filipino Men into the Long Haul Fishing Industry through Singapore.

57. Urbina I (2015) Tricked and Indebted on Land, Abused or Abandoned at Sea. The New York 


\section{TCEANA}

Times. Available: https://www.nytimes.com/2015/11/09/world/asia/philippines-fishingships-illegal-manning-agencies.html. Accessed Mar 29, 2018.

58. -- Email from government representative to Oceana (January 04, 2019 5:37 a.m. EST) (on file with Oceana).

59. -- (2011) Autopsy Report (Case No. PZ1151-02040). Health Sciences Authority Singapore.

60. -- (2011) Autopsy Report (Case No. 005-2011). Philippine National Police.

61. Defensor C (2011) Investigation Report Re: Death of Eril Andrade y Moales, Alleged Victim of Human Trafficking and Illegal Recruitment. Philippine National Police.

62. -- (2018) ICCAT Record of Vessels. AT000TAI00264, HUNG YU NO.212. International Commission for the Conservation of Atlantic Tunas. Available:

https://www.iccat.int/en/VesselsRecordDet.asp?id=26603. Accessed May 9, 2018.

63. -- (2018) ICCAT Record of Vessels. LSPLV Transhipment Authorisation. ATO0OPAN00145, TUNA QUEEN. International Commission for the Conservation of Atlantic Tunas. Available: https://www.iccat.int/en/VesselsCarrierDet.asp?id=8775\&FlagID=005. Accessed May 9, 2018.

64. -- (2018) ICCAT Record of Vessels. LSPLV Transhipment Authorisation. ATO0OPAN00185, TUNA PRINCESS. International Commission for the Conservation of Atlantic Tunas.

65. -- Email from government representative to Oceana (January 19, 2019 6:08 am.m EST) (on file with Oceana).

66. Kroodsma DA, Mayorga J, Hochberg T, et al. (2018) Tracking the global footprint of fisheries. Science 908: 904-908. doi: 10.1126/science.aao5646

67. -- Letter from Oceana to vessel representative (December 18, 2018) (on file with Oceana).

68. Santosa MA, Husein Y, Dalimunthe PR, et al. (2016) Report on Human Trafficking, Forced Labour and Fisheries Crime in the Indonesian Fishing Industry. International Organization for Migration.

69. McDowell R, Mason M and Mendoza M (2015) AP Investigation: Slaves may have caught the fish you bought. Associated Press.

70. -- (2015) Indonesian Minister of Marine Affairs and Fisheries Reiterated the Importance of Law Enforcement on IUU Fishing Practices in Indonesia. Embassy of the Republic of Indonesia. Available: http://www.embassyofindonesia.org/index.php/2015/04/04/indonesian-minister-ofmarine-affairs-and-fisheries-reiterated-the-importance-of-law-enforcement-on-iuufishing-practices-in-indonesia/. Accessed Feb 12, 2018.

71. -- (2017) International Convention on the Protection of the Rights of All Migrant Workers and Members their Families - Republic of Indonesia [CMW/C/IDN/1]. United Nations.

72. -- (2016) Legal Decision No. 105/Pid.Sus/2015/PN.Tul.

73. -- (2016) Legal Decision No. 106/Pid.Sus/2015/PN.Tul.

74. - - (2016) Legal Decision No. 107/Pid.Sus/2015/PN.Tul.

75. -- (2016) Legal Decision No. 108/Pid.Sus/2015/PN.Tul.

76. - - (2016) Legal Decision No. 109/Pid.Sus/2015/PN.Tul.

77. - - (2016) Legal Decision No. 110/Pid.Sus/2015/PN.Tul.

78. - - (2016) Legal Decision No. 111/Pid.Sus/2015/PN.Tul.

79. - - (2016) Legal Decision No. 112/Pid.Sus/2015/PN.Tul.

80. -- (2018) IOTC IUU Vessel List 2018. Indian Ocean Tuna Commission. Available: https://www.iotc.org/sites/default/files/documents/2018/12/2018-49_- 


\section{OCEANA}

_Amended_2018_IUU_Vessels_ListE.pdf

81. -- (2018) Dossier for proposal to include the carrier vessels, RENOWN REEFER ( ex WISDOM SEA REEFER ) into the Draft IUU Vessels List , pursuant to IOTC Resolution 17 / 03. Indian Ocean Tuna Commission. Available: http://www.iotc.org/sites/default/files/documents/2018/03/Dossier_of_CV_Draft_IUU_Ve ssels_ListE.pdf

82. -- (2016) Resolution 16/11 on Port State Measures to Prevent, Deter and Eliminate Illegal, Unreported and Unregulated Fishing. Indian Ocean Tuna Commission.

83. -- (2017) International Linkage - Assurance and Sustainability Press Conference. Results of Taiwan's Work on Combating IUU Fishing. Council of Agriculture. Available: https://www.fa.gov.tw/en/Announcement/content.aspx?id=50\&chk=f006f8ba-a4ca-40f6a3bc-729e79b14d5c Tm=. Accessed May 9, 2018.

84. -- Conservation Measure 13/09 on an Interim Prohibition of Transshipments - at - Sea in the SEAFO Convention Area and to Regulate Transshipments in Port. South East Atlantic Fisheries Organisation. Available: http://www.seafo.org/media/c130500c-84bf-435faba0-c13479dcabe2/SEAFOweb/CM/open/eng/CM13-09_pdf

85. -- (2009) Council Regulation (EC) No 1224/2009 of 20 November 2009 establishing a Community control system for ensuring compliance with the rules of the common fisheries policy. European Commission.

86. -- (2017) The FiTI Standard. Fisheries Transparency Initiative. 


\section{OCEANA}

\section{Appendix - Global Fishing Watch Data Methods}

Fishing Activity

Any and all references to "fishing" should be understood in the context of Global Fishing Watch's fishing detection algorithm, which is a best effort to determine "apparent fishing effort" based on vessel speed and direction data from the Automatic Identification System (AIS) collected via satellites and terrestrial receivers. ${ }^{e}$ As AIS data varies in completeness, accuracy and quality, and the fishing detection algorithm is a statistical estimate of apparent fishing activity, it is possible that some fishing effort is not identified and conversely, that some fishing effort identified is not fishing. For these reasons, Global Fishing Watch qualifies all designations of vessel fishing effort, including synonyms of the term "fishing effort," such as "fishing" or "fishing activity," as "apparent," rather than certain. Any/all Global Fishing Watch information about "apparent fishing effort" should be considered an estimate and must be relied upon solely at your own risk. Global Fishing Watch is taking steps to make sure fishing effort designations are as accurate as possible.

\section{Possible Port Visits}

Global Fishing Watch defines ports as any 0.5-kilometer grid cell with 20 or more unique vessels stationary for greater than 12 hours. A port visit includes the port entry and exit of a vessel. A vessel "enters" port when it is within 3 kilometers of a Global Fishing Watch-defined port and has slowed to a speed of 0.2 knots. A vessel "exits" port when its speed has increased to 0.5 knots and it is at least 4 kilometers away from the previously entered port.

\section{Possible Transshipment Events}

A possible transshipment is defined as when two vessels are within 500 meters of each other for longer than two hours while traveling at less than 2 knots and more than 10 kilometers from a coastal port.g,h

\section{Gaps in AIS Transmission}

Coverage gaps in the transmission of AIS were determined by identifying the locations where an AIS signal disappeared for more than 48 hours which can result when a vessel operator turns off its AIS or travels in a region with poor satellite coverage or high vessel density.

\footnotetext{
e Kroodsma D, Miller N, Mayorga J, et al. (2018). Tracking the Global Footprint of Fisheries. Science. DOI: 10.1126/science.aao5646

${ }^{\mathrm{f}}$ https://globalfishingwatch.org/datasets-and-code/anchorages/

g Miller N, Roan A, Hochberg T, et al. (2018) Identifying Global Patterns of Transshipment Behavior. Front. Mar. Sci. https://doi.org/10.3389/fmars.2018.00240

${ }^{\mathrm{h}}$ https://globalfishingwatch.org/transshipment-success/report-first-global-view-transshipment-sea/
} 